\title{
Maracatunaíma \\ Musical Semiotics, the Northeastern \\ Imaginary and the Sound of Fortaleza
}

\author{
Danielle Maia Cruz \\ Universidade Federal do Ceará
}

\author{
Michael B. Silvers \\ University of California, Los Angeles
}

In a small studio on the top floor of a commercial building in Meireles, a neighborhood that runs along Iracema beach in Fortaleza, Ceará, amid a strip of travel agencies and souvenir shops, we met three of the members of the band Eletrocactus, a contemporary rock group that generally combines American blues and rock with musical techniques that the band considers cearense (from the state of Ceará), nordestina (from the northeast of Brazil), and Brazilian. ${ }^{1}$ Many of their songs are played with baião, coco, maracatu, and frevo rhythms, indigenous to the region. The singer at times mimics cantoria, a sung poetic tradition associated with the interior of the state, by using a nasal tone, and takes inspiration from the fast, almost monotonous singing of embolada. The harmonic structures of their songs and melodic scales, however, generally owe more to classic rock and blues than to Brazilian musical traditions.

On that particular day, they were mixing their first album, which was to be released within the next few months at a show in Fortaleza's Theatro José de Alencar. Mauricelio, the band's drummer, and Gledson, the guitarist, entered into an argument. For Mauricelio, the $\mathrm{CD}$ needed to represent the band's roots: he wanted to amplify the sound of the iron triangle in the song

\footnotetext{
1 The authors of this article conducted fieldwork together in 2009-2010 in Fortaleza, Ceará, in which they interviewed members of Eletrocactus, observed a CD mastering session in a recording studio as well as rehearsals, and attended their CD release party. Danielle Maia Cruz, doctoral student in sociology at UFC, has researched maracatu cearense since 2006 in Fortaleza. She is currently researching relationships between municipal power and carnaval practices in Fortaleza, specifically related to public policy concerning carnaval and maracatu. Michael Silvers, doctoral student in ethnomusicology at UCLA, spent nine months in Fortaleza studying urban music that imagines the sertão (through rhythms, melodies, timbres, lyrics, and otherwise) with funding from Fulbright-mtvU.
} 
"Homens de Maracatu" (Men of Maracatu). The iron triangle is an instrument used in maracatu cearense, a musical and cultural practice in Fortaleza that recalls the court and coronation of the reis negros, the black kings of religious brotherhoods, principally during carnaval. (According to Souza (2002), there are indications that coronations of reis negros have occurred in the context of religious brotherhoods - and elsewhere-in various countries around the world since the sixteenth century.) Since at least 1937, the triangle has been one of the primary instruments in maracatu cearense. Moreover, the trianglea thinner steel version - is one of the three basic instruments of forró and baião, which are northeastern rhythms and genres often associated with rurality and the sertão, the Brazilian semi-arid hinterlands. According to Calé Alencar, maracatu musician and president of maracatu Nação Fortaleza, the use of the triangle in maracatu cearense (an instrument not used in the betterknown maracatu from the Brazilian state of Pernambuco and elsewhere) was inspired by the triangle used in baião ${ }^{2}$. Because of the iron triangle's high pitch, its sound carries easily over the drum ensembles that march during maracatu presentations. While the iron triangle can be played in a number of ways, there is one characteristic rhythm (accented on beats two and four in 4/4 meter in a slow tempo, often described by maracatu musicians as "cadenciado," cadenced) played by many of the maracatu groups in Fortaleza.

Although Mauricelio-who also plays drums in a rock cover band in a restaurant every Friday night - has no musical affiliation with Fortaleza's maracatu groups, to him, the rhythm and timbre of the triangle seemed like significant musical representations of the band's image. Gledson, the guitarist, wanted louder Led Zepplin-influenced electric guitar and less triangle. One could argue that the preference for guitar versus triangle (and vice versa) merely reflects the self-interest of the musicians (i.e., the guitarist wanted to hear more of himself in the mix), yet Mauricelio positioned his aesthetic argument within a discourse of regional and local identity, hoping to emphasize the contrasts between the sound of the triangle with the electric guitar without losing the local sound that to him defined the band. Agreeing with Mauricelio, Gleucimar (one of the group's lyricists and singers) explains the major intent of Eletrocactus is to "make music that represents the average

2 Thanks to Ron Conner (doctoral student in ethnomusicology at UCLA whose MA thesis concerned maracatu cearense) to whom Calé Alencar explained the history of the triangle in maracatu cearence in an interview on July 31, 2010, Fortaleza, Ceará.. 
person from Ceará."3 Roberto, the lead singer, reiterates, "We want to make music in which Cearenses (people from Ceará) can recognize themselves.”

Their intent, however, is not only one of self-representation, but also one of cultural preservation and promotion. They worry that traditional music from Ceará is undervalued and poorly known, and Gleucimar argues that "culture is ephemeral" and must be "preserved." This idea-that culture must be resurrected and taught so as not to be forgotten — at times contradicts the very principle that their music represents people from Ceará. How can people recognize themselves in something they do not yet know? According to Aragão (2005), in the second administration of the so-called "Government of Changes"' in Ceará, the state actively promoted a new touristic image of Ceará. Consequently, the primary representations of Ceará put forth by the media, the government and the local tourism industry until recently involved the sun, the ocean, and the beach, images that were part of the 1991 public policy campaign in which the state adopted the slogan, "Ceará Terra do Sol," Ceará Land of the Sun (Aragão 2005: 91). Cultural and musical representations (as opposed to geographic visual representatinos) of Ceará, however, remained less common. As such, the members of Eletrocactus believe they must first learn and then disseminate the sounds and images that they understand to represent their fans.

The problem, thus, is semiotic. On the one hand, they firmly believe that the musical (and visual) signs that they use to represent their band will be understood by their listeners as symbols of Ceará, the Northeast, and Brazil. On the other hand, they believe that these signs are under-appreciated and little-known. In this paper, we argue that this tension in their construction of the regional imaginary permits the multiple, conflicting, and contrasting ways Eletrocactus and its members locate themselves (and other musical groups) within the sociocultural context of present-day Fortaleza and the history of regionalist musical and cultural movements in Brazil, Ceará and Fortaleza. That is, their belief that there exists a lack of familiarity with the images and sounds that they consider regional gives them flexibility to create a new musical sound, audiovisual aesthetic, and cultural movement.

3 This translation (and all others) by the authors.

4 This was a political period in Ceará from 1987-2002 with successive administrations of mayors and governors affiliated with the PMDB and the PSDB. See Barbalho (2005). 
Applying Peircian semiotics to the study of music, Thomas Turino claims, "Music involves signs of feeling and experience rather than the types of mediational signs that are about something else," thereby allowing music "to create emotional responses and to realize personal and social identities" (Turino 1999: 224). For Eletrocactus, their music and self-presentation includes both "signs of feeling" and "mediational signs," what Peirce (and Turino) would call an "emotional interpretant" and a "sign-interpretant," the former meaning that it instigates a feeling, the latter meaning that it corresponds to a "linguistic-based concept" (Ibid.). By symbolizing the state of Ceará, the band expects to evoke feelings of attachment and self-recognition. Turino argues, "We make the connection between indexical signs and their objects by experiencing them together in our actual lives," and claims that, for example, we associate wedding marches with weddings because we have previously experienced hearing the two occur together (Turino 2008: 9). Here, we argue that it is both lived experience as well as cultural learning and reiteration that give musical signs their power. Maracatu cearense is not a musical sign of Fortaleza because listeners have heard it within the boundaries of Fortaleza. Eletrocactus employs it as a symbol because the band's members have previously learned that it - as opposed to other kinds of music-is a sonic representation of the city. Moreover, they continue the process of giving these local, regional and national signs their meaning.

In her article, "Macunaíma's Music," Suzel Reily argues, "We are now faced with the difficult task of critically dismantling the tri-ethnic mythologies of the twentieth century if we are to understand what music means to those who perform it" (Reily 1997: 94). The regionalist imaginary utilized by Eletrocactus illustrates elements of the Brazilian "myth of the three races"the idea that Brazilians are of European, African or indigenous ancestry, or some mix of the three-as observable in their song, "Maracatunaíma," its title alluding to both Mário de Andrade's nationalist novel, Macunaima, and to maracatu cearense. According to the band, this song treats the blues simultaneously as a global, decontextualized signifier of whiteness and as a signifier of the melancholy of enslaved Africans in the United States. They treat maracatu as a musical symbol of Fortaleza as well as of the sadness of enslaved Africans in Brazil. Its lyrics, which quote the book, Macunaima, reference indigenous imagery. While "race" - understood here as a social construction (Boas 1940; Fry 2005) - is not the focus of this article, it remains 
a noteworthy element of Eletrocactus' musical imaginary, especially in the song, "Maracatunaíma."

As revealed through interviews, even while some members of the group are strongly influenced by rock, Eletrocactus imagines itself as a product of a diverse intellectual and musical lineage that includes Oswald de Andrade's Manifesto Antropofago from the Semana de Arte Moderna in the 1920 within the national ambit, the so-called Pessoal do Ceará of the 1970s within the state-wide scope, and the Movimento Cabaçal of the early 20oos, a musical movement which primarily limited itself to the city of Fortaleza (but also included a band from Juazeiro do Norte). The band's musical and philosophical antecedents-specifically, the music of the Pessoal do Ceará and the Movimento Cabaçal—generated and promoted many of the musical and visual signs of the national and regional imaginary used by Eletrocactus. Some of their chosen images are also rooted in the history of Brazilian film (e.g., Glauber Rocha's Deus e o Diabo na Terra do Sol), literature (e.g., Raquel de Queroz's $O$ Quinze), and the media in general. Rhythms like the baião and xote became associated with the Northeast throughout Brazil as early as the $1940 \mathrm{~s}$ due to the radio and the music of Luiz Gonzaga, a singer, accordionist, and songwriter often referred to as the "king of baião" (Albuquerque Jr. 1999: 174). However, some of the signs employed by Eletrocactus' musical and visual imaginary are also original. By combining already recognized images and sounds with new ones, Eletrocactus disputes the meaning of local, regional and national identity.

In situating itself within various musical scenes, genres, and histories, the tensions in how Eletrocactus' members present and understand themselves exist in various dichotomous dimensions: Fortaleza and Ceará (urban and rural), Ceará and the Northeast (state and region), the Northeast and Brazil (region and nation), and Brazil and the world (local/national and global). To demonstrate these tensions that permeate their music, appearance, lyrics, and spoken discourse, we first contextualize the band and their musical project within the history of Brazil, Ceará, and Fortaleza and how and why these different individuals see themselves as belonging to various musical and intellectual movements. Next, we analyze their CD release party, an event which helped introduce Eletrocactus to the local scene, showing the present-day musical and social context. Last, we interpret the song, "Maracatunaíma," which demonstrates how they musically dialogue with a 
racialized discourse concerning what it means to be from Ceará and northeastern Brazil today.

\section{The Pessoal do Ceará: Imagining the State}

Eletrocactus was initially formed in 2001 by siblings Gleucimar and Gledson, who moved to Fortaleza from Rio de Janeiro in 1993. The two often performed music together at home-Gleucimar wrote lyrics, while Gledson wrote melodies - and decided to play together at an event called the Feira de Jiriquiti in Fortaleza. According to Gleucimar, a producer heard them singing at the function and invited her and her brother to perform Gledson's musical arrangements of her poetry at another event. The two had no band, much less a repertoire, so they invited three of Gledson's friends, a group of rock musicians who already played together, to accompany them on stage. Thus was born Projeto Cactus, as they first called their band, according to Roberto in a personal interview.

After arriving in Fortaleza, Gleucimar says that she already felt a strong sense of belonging and an attraction to many of Ceará's cultural manifestations, including literatura de cordel, a kind of folk poetry, and maracatu cearense. Gleucimar also took an interest in the music of the so-called Pessoal do Ceará, the folks from Ceará, as several successful musicians from Ceará were known in the 1960 s and 7os, including Ednardo-Gleucimar's favorite-Fagner, and Belchior. After marveling at the local culture, which to her seemed different from that of urban Rio de Janeiro, she felt compelled take part in a movement for cultural preservation. As she explained, if "ephemeral" culture is not preserved, it will cease to exist, a sentiment that recalls Alan Lomax's fear of "cultural grey-out." Yet in the case of Gleucimar, her method of "preserving" regional culture was to modify it, to combine her love of regional culture with her brother's affinity for heavy metal and Led Zepplin. Nonetheless, she understands Eletrocactus as a tool among many for salvaging regional music and culture.

Regionalist musical movements, however, are not new to the musical scene in Ceará. Beginning in the early 196os, a student movement known as the União Nacional dos Estudantes (UNE), founded in Rio de Janeiro before becoming active throughout the nation, helped spread a cultural-political ideology that gave rise to regionalist and nationalist cultural movements. The 
UNE's Centro Popular da Cultura (CPC), its cultural wing, stood by a motto, "fora da arte política não há arte popular" (outside of political art there is no popular art). In 1964, the same year as the coup d'état that began the twenty-one year military dictatorship, a group of students at the Universidade Federal do Ceará (UFC), mostly actors and musicians, came together to form CACTUS, an activist art/theater/music organization to realize the mission of the CPC though concerts and theatrical performances. Their shows included songs by well-known bossa nova musicians like Nara Leão and Edu Lobo. However, as political repression began silencing activists and musicians throughout Brazil, CACTUS was derided as a communist organization, and as sociologist Mary Pimentel implies, members were thrown in jail. Despite the group's losses to the military regime, CACTUS reconfigured in 1965, mostly by students from the physics department at UFC who refocused its efforts on cinema. Members like Rodger Rogério created a traveling "caravan," and toured around the interior of Ceará and the nearby state of Rio Grande do Norte showing films as their newly adopted method of cultural-political activism (Pimentel 1995: 76-8).

In 1966, a second Fortaleza-based organization called GRUTA (Grupo Universitário de Teatro e Arte), comprising students predominantly from the College of Architecture and Urbanism at UFC, took up the CPC's mission of populist political art. Members, including landscape architect and songwriter Ricardo Bezerra, Fausto Nilo, and Petrúcio Maia, viewed GRUTA as a regionally, locally focused organization, in contrast to CACTUS, which utilized more nationalist discourses and a musical, theatrical and cinematic repertoire that came from the Brazilian Southeast. GRUTA's songs, plays, and performances were generally written by local musicians and writers, and they toured the nation in "cultural caravans" to spread what they understood as cearense culture (Ibid.: 79-80). The names of both organizations drew on the two primary images of Ceará's geography: cactus, an easily recognizable index of the sertão (the Brazilian hinterlands), and gruta, meaning cavern, many of which can be found in beach towns along Ceará's coast like Taíba and Canoa Quebrada. Throughout Ceará's recent musical history, these two geographical images - the sertão and the beach — have competed for space in the local imaginary.

CACTUS and GRUTA along with the contemporary musical and political climate gave rise to a new musical scene in Fortaleza, and musicians like 
Fagner, Belchior, and Ednardo, who began to compete in nationally televised music festivals, gained national recognition. They, as well as Amelinha, Rodger Rogério, and Teti, came to be known as the "Pessoal do Ceará," the folks from Ceará. The Pessoal do Ceará, like the Tropicalistas, were never a singular group, but rather a collection of individual musicians that were seen as part of the same musical movement. Each musician had a unique sound: Fagner combined the baião and music from the rural interior with international sounds like Indian rags and the sound of the sitar (played instead by a viola caipira), free jazz, psychedelia, and the ballads of jovem guarda musicians like Roberto Carlos; Ednardo was similarly influenced by the jovem guarda; while Belchior came to be referred to as the Brazilian Bob Dylan, influenced by the American folk revival and Dylan's poetic lyrics. Describing what united this diverse group of musicians, Rodger Rogério explained:

"In the transformation of each of us, there was one thing in common, which was Luiz Gonzaga. While for Fagner and Ednardo, Roberto Carlos was a heavy influence, for me and Petrúcio [Maia] it was bossa nova. Alongside these two things [Roberto Carlos and bossa nova], there was the past ... Brazilian music in general and northeastern music; lots of influence from Luiz Gonzaga and Jackson do Pandeiro" (In Castro 2008: 45). ${ }^{5}$

It is important to note that while Tropicalismo and similar anthropophagist musical movements were appearing elsewhere in Brazil at the time, the Pessoal do Ceará did not see themselves as an offshoot of Tropicalismo but as something uniquely cearense. These movements arose from similar cultural and musical backgrounds - a national musical history that included Beatlemania and an affinity with international counterculture movements, a steady decline in the popularity of bossa nova, and UNE-inspired student movements that were beginning to act in response to the military dictatorship — but each was aimed at a slightly different audience and generated by different circumstances. Ricardo Bezerra describes the music of the Pessoal do Ceará as "cosmopolitan," sometimes drawing on tango and the bolero, other times drawing on rock and American folk music (Castro 2008: 47). While this kind of hybridic musical borrowing is reminiscent of

5 Jackson do Pandeiro (1919-1982), like Luiz Gonzaga (1912-1989), is considered one of the great innovators of northeastern Brazilian music. 
Tropicalismo, discourses surrounding cultural anthropophagy generally associated with Tropicalismo were of little concern to the Pessoal do Ceará.

In an analysis of the image of Ceará in the music of Ednardo, Gilmar de Carvalho argues that by citing places and rhythms from Ceará in his music, Ednardo created original cearense music that was neither athropophogist nor preservationist. "Folklore enters his music as a starting point in his creative process, and not as a diluted pastiche among modern arrangements or enclosed in pretentious structures" (Carvalho 1983: 11). Gleucimar understands the regionalism of the Pessoal do Ceará as deriving from the modernist ideas of Oswald de Andrade. She asserts, "The Semana de Arte Moderna did not arrive in Ceará until the 197os." As she sees it, the Pessoal do Ceará were the first wave of musicians and artists in Ceará to create art inspired by local traditions, following the principles of the event that occurred in 1922 in the Municipal Theater of São Paulo. At the Semana de Arte Moderna (Modern Art Week), artists and intellectuals strongly influenced by aesthetic ideas from Europe presented paintings, sculptures, poetry, literature and music. It was considered the beginning of Brazilian Modernism. According to Lima (2009), the first efforts of the artists involved with the event sought to elevate the national arts to the quality of those in European avant-garde movements. It is important to understand the diversity of the artistic output resulting from the Semana de Arte Moderna, and not ascribe to it a homogenized vision of nationalism, which was not a primary concern until after 1924 .

Many of the Pessoal do Ceará enjoyed popularity throughout the 197os, due in part to the fact that many of them deliberately referenced the sertão and the Northeast to give themselves an air of northeastern authenticity and distinguish themselves on the national scene from musicians from other regions. Fagner, who was raised in Orós, a small town in the interior of Ceará, had his first hit with the song "Mucuripe," about a beach in Fortaleza known for its fishermen and jangada fishing rafts. "Mucuripe" was also included on his LP, "Último Pau de Arara,", its title track (composed by Venâncio, Corumba and José Guimarães) about a man's reluctance to leave his drought-ridden home in the sertão. Ednardo also drew on the visual imagery of the state, as in his 1991 music video for the song "O Romance do Pavão Mysterioso" (originally recorded in 1974) filmed from

6 The album was released as both "Último Pau de Arara" and "Manera Fru Fru, Manera” 
the top of a dune at Cumbuco beach approximately twenty-five kilometers from Fortaleza. In the original recording of the song, a maracatu cearense rhythm accompanies the melody. Ednardo can be seen from atop another dune in his video for "Terral," a song frequently described as the "anthem of Fortaleza." For "Terral," the visual choice was fitting: the lyrics begin, "Eu venho das dunas brancas/onde eu queria ficar" (I come from the white dunes/where I wanted to stay).

Gleucimar believes that Ednardo and his music are representative of the city of Fortaleza, while Fagner's music represents the rural interior. She explains, "Ednardo was a city man, and you can see it in his musicality, even in the maracatu, which you only have in the state capital and not the interior." On the other hand, Fagner (who is of Lebanese descent) "was a man of the interior ... he had contact with Arabic music." Many people describe the music of the interior of northeastern Brazil as having Arabic influences, especially the intonation, the instruments (like the rabeca, a kind of fiddle), and the scales, which are also often associated with Medieval church music (Brandão 1971; Paz 2002).

Maria das Dores Nogueira Mendes confirms the plurality of signs, images, and visions of Ceará evident in the music of the Pessoal do Ceará. They "think of Ceará and the Northeast in their various realities, almost always through the prism of questions and the characteristics of each space, thus instituting an identification with a plural place that overcomes those already known homogenizations created by other discourses" (Mendes 2007: 414).

\section{Calé Alencar and Maracatu Cearense: Imagining the City}

In 1995, several musicians associated with the Pessoal do Ceará decided to perform together at Fortal, a yearly festival held in Fortaleza since 1992 in which bands play rhythms like axé music, a popular dance genre from the state of Bahia, atop trios elétricos (large trucks mounted with sound systems). Calling themselves Balanço da Massa, singers like Ednardo, Rodger Rogerio, Calé Alencar, and Carol Demasceno played music exclusively written by composers from Ceará, including by themselves. According to Calé Alencar, musician and current president of maracatu cearense group Nação Fortaleza ${ }^{7}$, the

7 Maracatu groups are often referred to as "maracatus" or as "nações," nations. See more about this 
purpose of Balanço da Massa was "to show something that would represent us as a place with its own music, musicality, its own rhythms. And maracatu was part of that."

In the same period as the Balanço da Massa performance at Fortal, Calé Alencar was invited to compose a loa (the term for a maracatu cearense song) for maracatu Nação Boabab, thus inserting himself into the universe of $m a-$ racatu cearense. For the next five years, Alencar was a member (or brincante, meaning player) of maracatu $\mathrm{Az}$ de Ouro, and in 2004 founded maracatu Nação Fortaleza. In an interview, Calé suggested that he views his maracatu group as a tool for expressing cearensidade (cearense-ness). While other maracatu groups try to represent Ceará and cearensidade with stories and lyrics about Fortaleza and Ceará, Calé Alencar hopes to represent the city and state with the music of maracatu-the sound itself. He signifies place with compositions, timbres (e.g., the sound of the iron triangle), and instrumentation (e.g., drums and other percussion instruments he invented, like a corn grater decorated with colored ribbons from the city of Juazeiro do Norte bearing the name Padre Cicero, a famous priest considered a saint by many people in the Northeast). His instrument, the onomatopoetically named chico-chico, produces a sound he says resembles the sound of the traditional reco-reco; it is played by striking a wooden stick attached to a bicycle rim against a corn grinder.

Calé associates maracatu with urban Fortaleza, evident by his choice to name his group Nação Fortaleza, by performing the city's anthem, and due to the fact that maracatu cearense only exists in the state capital. ${ }^{8}$ However, by also mentioning individuals like author José de Alencar and Calés own famous grandmother Bárbara de Alencar in his lyrics, by performing popular songs by local composers like Ednardo's “O Romance do Pavão Misterioso” as Nação Fortaleza's carnaval theme in 2006, and by using colored ribbons that refer to Juazeiro do Norte, he also links maracatu to the state of Ceará. Thus, in some contexts Nação Fortaleza emphasizes the image of the city, and in others it emphasizes the state, notably during carnaval. In other moments it emphasizes the Northeast or Brazil, which occurs when maracatu Nação

\footnotetext{
subject in Lima and Guillen (2007), Lima (2008).

8 There are no known records of maracatus in cities in the interior of the state according to the Secretaries of Culture of the municipality of Fortaleza and the state of Ceará. However, in an interview conducted by Danielle Maia, the researcher Oswald Barroso referenced the existence of a now-defunct group in the city of Itapipoca.
} 
Fortaleza performs abroad or elsewhere in the country. This can be perceived by the use of chita (cotton fabric with vibrant colors and floral prints, a stereotypical image of the region) on the participants' costumes and decorating their drums.

Calé defines maracatu as a cultural manifestation that reenacts the parades and coronations of the black kings of religious brotherhoods from the period of slavery. Cruz (2011) elaborates on this idea, explaining that all maracatus that present during carnaval in Fortaleza, in their reenactment of the court and coronation of the black kings, include groups (called alas) of participants dressed as stereotyped indians, blacks, baianas (stereotypical women from the state of Bahia), preto velhos (old black people), a calunga (a woman carrying a doll), the royal court, drummers, and orixás (the deities of Afro-Brazilian religion). While each maracatu group has these elements in common, each group also has its own peculiarities which configure it as an instrument of social and political expression for its members.

Possibly, the widely understood correlation between maracatu and the coronation of the so-called black kings are related to the diffusion of knowledge by Costa (1908), Ferreira (1951), Real (1967), Guerra-Peixe (1980), Rodrigues (1932), Andrade (1981) and others who participated in the propagation of categorizations of maracatu, homogenizing many of the dynamics inherent in the practice. Costa (1908) strongly perpetuated the idea that maraca$t u$ was reminiscent of Africa, and Rodrigues (1931) spread ideas about totemic survivals. However, articulating a precise definition of maracatu is a complicated task because of the multiplicity of uses and meanings given to maracatu in distinct times and places. ${ }^{9}$ Houaiss Dictionary defines it as "a dance in which a costumed group, dancing to the sound of drums, shakers and bells (gonguês), is followed by a woman, who carries in her hand a bat at the end of which is a richly decorated doll (the calunga) and is executing choreographic evolutions." Still, to understand the concept by the dictionary's definition implicitly homogenizes the manifestation around a single idea and ignores its processual and plural character. Depending on the place, the definition of a practice like maracatu is anchored in some elements like the use of specific instruments, the presence of specific characters, the presence of musical

\footnotetext{
9 There are, for example, self-described maracatu groups in the United States and Europe with Brazilian and foreign members.
} 
rhythms, and the involvement of participants with a specific religion. For example, Lima (2009) said, regarding the historic composition of maracatu pernambucano, that Afro-Brazilian religions like candomblé, umbanda, and jurema have been fundamental in the legitimization of the cultural practice in the state of Pernambuco. To limit the plurality of these practices only to the coronation of the black kings or in categorizations like "baque solto" and "baque virado" (two distinct maracatu rhythms) implies an attempt to essentialize the manifestation and, moreover, ignores the tensions, negotiations and disputes regarding the cultural practice.

In Ceará, despite the fact that maracatu participants legitimize their maracatu groups with the presence of a "queen" (who is generally played by a man), a calunga (a woman carrying a doll), a balaieiro (a man with a basket of fruit on his head), the group of indians, of baianas, and the casal de preto velho (the old, black couple), the practice is still dynamic and marked by innovation. Calé Alencar, for example, who categorically affirms that he "respects the traditions" taught by masters like Juca do Balaio, Afrânio de Castro Rangel and Raimundo Boca Aberta regarding the various alas, the smaller groups within a maracatu, especially the royal court, and the use of blackface, nevertheless says the intent of maracatu Nação Fortaleza is to innovate. Since the inception of Nação Fortaleza, he chose to have a woman play the role of the queen, changed the traditional four beats played on the snare drum to six beats, raised the pitch of the maracatu triangles, and modified other traditional maracatu rhythms. The instruments commonly played in maracatu cearense are drums, triangles, snares, and chocalhos (shakers).

According to Silva (2004), the maracatus in the 1930 s played faster rhythms, and this practice lasted for more than ten years. In the 1950s, maracatu Az de Espada began playing maracatu in a slower tempo, described as "cadenced." Silva asserts all maracatu groups that began playing the new, slower tempo ultimately adopted it, transforming it into a significant characteristic of maracatu cearense. Near the end of the ' 80 s, maracatu Nação Verdes Mares presented with a faster tempo and in 1995 Nação Boabab mixed the "cadenced" rhythms with others, like the baque-virado rhythm from maracatu in Pernambuco, also introducing an instrument called the chocalheira. During those years, maracatu cearense groups mixed different rhythms: Nação Boabab incorporated xaxado, coco, and baque-virado, and Nação Iracema, Nação Rei Zumbi, Nação Fortaleza, and Nação Solar play faster rhythms and invent new instruments. 
The iron triangle has been important in maracatu cearense since the 1930s, and according to Calé, "there is no maracatu in the world [other than Cearás] that uses the iron triangle." The utilization of the instrument also proves the desire to mark the distinction between maracatu in Ceará and maracatu from the state of Pernambuco. As Calé explained, he became involved with maracatu in part to combat misconceptions that maracatu cearense is an imitation of maracatu pernambucano. Regarding these distinctions, he says:

There are many differences: the costumes, the dance, the organization, the instruments, and the fact that we don't leave from a terreiro (place of worship) for our parade. Maracatu cearense is a game, a part of carnaval. The maracatu cearense groups don't have a deeply religious significance $[. .$.$] like they have with$ rigor in maracatu pernambucano.

While most maracatu cearense groups are associated with specific neighborhoods, Nação Fortaleza is notable in that it brings together people from different neighborhoods and social and cultural conditions. During carnaval, many college students participate in Nação Fortaleza, including individuals associated with cultural and musical movements in Ceará, like Gleucimar, who played in Nação Fortaleza for several years. The presence of activists and skilled musicians in Nação Fortaleza is likely a result of Calé's belief that music is capable of expressing cultural identities. He said in an interview that he always tries to work with "rhythms that express a cultural identity," and included a maracatu loa on his first album. His intent is to disseminate "this kind of rhythm, music, and theme to show our identity.” Calé emphasized the importance of the interaction between Nação Fortaleza and local bands like Eletrocactus. He sees exchanges with young musicians as fundamental because of their "young blood," in addition to the fact that these singers understand the music, notably the loas of maracatu, as a way to propagate cearensidade.

Maracatu began acquiring meaning, however slowly, as a sign of cearensidade over many decades. Participants dedicate themselves annually to the process of preparing these elaborate presentations, especially for carnaval. Recently, there has been municipal interest in maracatu during carnaval. The city has greatly increased its financial support of carnaval (from $\mathrm{R} \$ 80,000$ in 
$2001^{10}$ to $\mathrm{R} \$ 370,000$ in $\left.2009^{11}\right)$, hoping to raise the visibility and importance of maracatu in local culture.

At the maracatu parade during carnaval on Avenida Domigos Olímpio in 2006, mayor Luizianne Lins described maracatu as "part of our cultural identity," referring to new cultural policies that have encouraged the valorization of the practice. Through current cultural policy, cultural manifestations are turned into signs of cultural identity, as has occurred in recent years with maracatu.

Gleucimar and Roberto's proximity to Calé Alencar has perhaps permitted the members of Eletrocactus to view maracatu cearense as a symbol of Ceará, as a practice that expresses feelings of belonging to the region, and this can be heard in their music. Gleucimar feels an especially strong connection with maracatu Nação Fortaleza, and describes Calé Alencar as "the man who creates maracatu where life does not create it" in her song "Homens de Maracatu."

Calé's commitment to spread the idea that maracatu is a symbol of Ceará was perhaps influenced by the Manguebeat movement from the state of Pernambuco in the 199os. According to Lima (2009a), in the 1980s and 'gos the Manguebeat Movement - propelled by the band Chico Science and Nação Zumbi-was paramount to the rise of maracatu as a symbol of Pernambuco. Nação Zumbi, which recorded the first album to have only maracatu, garnered success among young people from diverse social classes and also promoted maracatu as a local rhythm and practice.

According to Lima (2009a), the Manguebeat Movement was crucial in elevating the role and image of maracatu in Pernambuco. Nearly every maracatu group that emerged internationally and in other Brazilian states came after the release of the album "Da Lama ao Caos "(1994) and" Afro-ciberdelia" (1996), both by Chico Science and Nação Zumbi. On the influence of the Manguebeat Movement in Brazil, Lima points out that while various organized and active maracatu groups existed in Ceará before the appearance of the Manguebeat Movement, it is still possible to see its resonance in Calé Alencar's maracatu Nação Fortaleza (2009a: 123). Neither Calé Alencar nor Eletrocactus mention a direct influence of the Manguebeat Movement in

10 Jornal O Povo, 11 de janeiro de 2004. "Muita idéia e pouca definição"

11 Source: www.secultfor.com.br accessed on 9/19/2010 
their music. However, Calé Alencar's initial involvement with maracatu and his performance of the Balanço da Massa at Fortal occurred in Fortaleza at the same time as Chico Science and Nação Zumbi became nationally successful. It is worth mentioning that in 2010, Nação Fortaleza was the first maracatu cearense group to release an album of loas. Although maracatu cearense is not yet widely legitimized as a symbol of Ceará, Eletrocactus' choice of maracatu as an expression of local and regional belonging can be understood as emerging from dialogues surrounding movements like the Pessoal do Ceará and the Movemento Cabaçal, as well as from their interaction with Calé Alencar. Furthermore, as a cultural practice, maracatu articulates several dimensions in which the band locates itself: the city of Fortaleza, the state of Ceará, the northeast region and Brazil as a whole.

\section{The Movimento Cabaçal: Youth and Nordestinidade}

In 2001, another regional musical/cultural movement known as the Movimento Cabaçal appeared on the scene in Ceará. The word "cabaçal" refers to cabaças, calabash gourds, which are grown in the dry interior of Ceará, and also to a kind of fife-and-drum ensemble (called banda cabaçal or banda de pífano) from the interior of the Northeast. The four original bands associated with the Movimento Cabaçal were Dona Zefinha, Dr. Raiz, Jumentaparida, and SoulZé. Their mission was to combine "international" rock music with traditional instruments and genres from Ceará, including the pifanos and zabumba drums of cabaçal music, the triangles and accordions of forró and baião, and the iron triangles and drums associated with maracatu cearense. In the movement's conception, rock music and electronic instruments were taken as signs of contemporaneity and global youth culture. For them, cearense traditional music was representative of the state and the region. They saw their music as a way of updating, celebrating, and preserving local culture.

Cristina Magaldi writes, "Symbols of brasilidade have to share their space with symbols of youth and symbols of modernity." (Magaldi 1999: 313). This is also true for signs of nordestinidade (northeastern-ness) and cearensidade, which also must share space with youth culture and modernity. In an interview, Orlângelo Leal, the lead singer of Dona Zefinha, asserted that these images share space in his work. He described his music as poetry "that speaks of the fears, the longings, the desires, about technology; that speaks of the 
northeastern man who lives in this amalgam of technology and ritual, sacred and profane, of urban and rural, of traditional and contemporary." The music of Dona Zefinha, the only one of the four groups to continue performing in Fortaleza today, combines the music and theatricality of reisados - a musical and theatrical tradition associated with Epiphany, a Christian holiday on the sixth of January, and practiced year-round in the Cariri region in Cearás interior - with the instrumentation and sensibility of rock. Their stage show often includes mestres de cultura, singers and dancers who are usually older, from rural areas and continue to practice the kind of traditional culture celebrated by the Movimento Cabaçal. In one of Dona Zefinha's shows in 2010, a mestre de cultura, a Brazilian tap dancer who had trained in New York City, and Orângelo shared the stage as they each danced their interpretation of the sapateado, a kind of northeastern tap dancing.

It is important to distinguish between the Movimento Cabaçal and the better-known Manguebeat Movement from Recife. Just as Manguebeat differed from Tropicalismo in terms of "social origins," "initial aesthetic options," and differing attitudes towards politics and ideology, the Movimento Cabaçal also differed from both Tropicalismo and Manguebeat (Vargas 2007: 8o-81). The music of Manguebeat combined northeastern traditional music, especially maracatu pernambucano, with hip hop, electronica, and rock, among other diverse styles, but was neither political nor intended to be mainstream like Tropicalismo. The Movimento Cabaçal drew from a smaller set of international influences than either Tropicalismo and Manguebeat and made intentional use of music from Ceará. For example, Dr. Raiz, from the city of Juazeiro do Norte in the Cariri region of Ceará, combines distorted guitars and screamed heavy metal-style vocals with zabumba drums and pifanos, and the band has no drum set. Dona Zefinha, which is as much a theater group as it is as a band, sees itself today as part of no political or social movement, but instead as part of a larger community of Brazilian musicians, artists, dancers and playwrights. The group has traveled to Europe and the United States to represent Brazil in festivals, so they feel more connected to Brazil as a whole than to Ceará specifically. Orlângelo Leal explains that Dona Zefinha "belongs" to Brazilian culture in general, and the Northeast is simply "one more element." ${ }^{12}$ Nonetheless, the Brazilian musicians and music that he

12 Orlângelo Leal, interview by Silvers, March 13, 2010. 
cites as his greatest influences are mostly from Ceará and the Northeast, including cantoria music, coco, embolada, Luiz Gonzaga, and Geraldo Azevedo, a singer from Pernambuco.

In recent years, since the Movimento Cabaçal's dissolution, new bands that play northeastern-influenced rock have begun appearing in Fortaleza. Groups including Água de Quartinha, Cordão de Caruá, Vigna Vulgaris (known for playing maracatu cearense) and Eletrocactus now perform in the city as a kind of unofficial second wave of the Movimento Cabaçal (and are sometimes referred to as such). ${ }^{13}$ In January of 2007, the Banco do Nordeste do Brasil (BNB) hosted its first annual month-long rock festival called RockCordel, which took place in both Fortaleza and Juazeiro do Norte and involved bands that played diverse rock styles and sub-genres. The lineup included newer groups like Eletrocactus and Vigna Vulgaris along with Dona Zefinha, Cidadão Instigado (arguably the best-known contemporary rock band to come from Fortaleza, now based in São Paulo), Calé Alencar and his maracatu Nação Fortaleza, and Ednardo. In 2010, the Rock-Cordel festival in Fortaleza had less of a regionalist tone, and featured more cover bands than anything else. In an open letter to the president of the Banco do Nordeste (dated November 26, 2009), the Associação Cultural Cearense do Rock (the Cearense Cultural Association of Rock) wrote that the event created "cultural spaces for a segment of the population that is often considered marginal and stigmatized," and proposed modifications to the event, mostly concerning the expense of performing and the $\mathrm{R} \$ 250$ per group payment, seen as meagre by the association. Because of the low pay, a number of musicians, many of whom come from lower income backgrounds, refused to perform that year. The original members of Eletrocactus all live in a neighborhood called José Walter, over fifteen kilometers from the city's downtown and considered part of the periphery. They performed in this year's Rock-Cordel, but in Juazeiro do Norte and Sousa, Paraiba, and not in Fortaleza.

In recent months, a new movement called Ceará Autoral Criativo (Creative Authorial Ceará) released a CD called Bora! (meaning, "let’s go!") with recordings by bands affiliated with the movement and its philosophy, which is to valorize original music composed by musicians from Ceará. Eletrocactus is one of twenty groups to appear on the CD.

13 The second wave of the Movimento Cabaçal is referenced in the blog Todos os Sons, for example. 
The recent changes in Rock-Cordel and the appearance of Ceará Autoral Criativo prove that musicians in Ceará need not perform music that sounds distinctly cearense (that is, regionalist) in order to identify or be identified as cearense. This shift is also audible in the music of Eletrocactus' first fulllength album.

\section{The CD Release Party}

Around 7 in the evening on Thursday, June 10, 2010 Eletrocactus released their album, O Dia em que a Fome Morreu de Sede (the Day that Hunger Died of Thirst), at the Theatro José de Alencar. The theater, currently recognizable as one of the most common post-card images of the city, was inaugurated in 1910 with a neo-classical façade and an art nouveau interior, common architectural styles for northeastern Brazil at that time (Barroso 2002: 42).

Today, the theater specializes in no singular genre or artistic medium, and has a daily agenda of concerts, plays, and events, as well as an educational program, has an academic researcher on staff, and holds an important place in the city's cultural landscape. Shows can be seen from the theater's various spaces, like its garden, main stage, coffee shop, annex, and foyer, with an upstairs space for private recitals and scholarly lectures.

On the night of Eletrocactus' CD release party, vendors selling popcorn, candy, and pirated CDs, hippies hawking hand-made jewelry, beggars and people hustling home from work crowded the sidewalk around the theater. The theater sits near an intersection with limited access, blocked by construction from a downtown revitalization project. On one side of the theater are stores selling housewares, inexpensive clothing, and beads, and on the other is a closed-off construction zone. Across the street, groups of workers sat at food carts eating grilled steak and chicken and drinking beer, presumably returning home from work. Intermingling with the downtown soundscape of traffic, shouting vendors, and the noise of chit-chat was the sound of the city's civic orchestra performing a medley of orchestral arrangements of songs by Luiz Gonzaga.

Some of those who gathered around the orchestra, playing in an outdoor courtyard between the theater's foyer and the main stage's doors, gave partial attention to the music, instead conversing; others listened quietly while drinking café espresso and snacking on popcorn they bought outside; and 
others, individually or in couples, sat in the garden to the side appreciating the sound of the orchestra. It seemed, however, as if no one had come for the explicit purpose of hearing symphonic baião. On the main stage in the theater, a play, scheduled to begin at the same time as the $\mathrm{CD}$ release party, began.

When the orchestra finished their Luiz Gonzaga medley with a version of "Asa Branca," often called the "anthem of the Northeast," now full of orchestral flourishes and contrapuntal detail, some listeners approached the musicians, some entered the main stage for the play, some left the theater, and many entered the verdant gardens, designed by famed Brazilian landscape architect Burle Marx, with a red brick patio, park benches, and Brazilwood trees. In front of the garden's concrete stage, people mingled, waiting for Eletrocactus to begin, passing time by reading, smoking, flirting and making conversation. Slowly, more Eletrocactus fans trickled in, waiting patiently around the tree-lined stage while one of the band members set up a table to sell their new album. Attendance was likely affected by the city's bus strike, which had slowed many business and cultural events in Fortaleza that week. Standing discretely behind the rest of the audience was Calé Alencar. The crowd was mostly friends and relatives of the band, along with some who had seen the announcement in the previous day's O Povo, Fortaleza's best-known newspaper, or in the press release the band sent out over the internet.

The concert was intended for a local audience- the band sees itself as part of a local scene-and the show was intended to be a celebration of their semi-official entrance on the scene. While the band has now existed for over six years, this is their first time making a full-length studio recording. The garden remained lit by the theater's external lights, and the iron fence separating the garden from the street allowed the sounds of cars and light from headlights and shops to filter in. On the back of the stage stood a video screen which, during the show, displayed psychedelically distorted footage of the band, filmed in real time by a camcorder on the lead singer's left side and modified on a notebook computer on a table in the middle of the stage. The wall behind the stage, covered in vines, and vertical stage rigging framed the band's seven members.

Eletrocactus' original formation included Roberto, a lead singer, who at times during the show played the iron and steel triangles of maracatu and forró; Gleucimar, a singer who often plays rhythm guitar and on this night also periodically played the ganzá, a metal shaker; Mauricélio, a drummer with 
shoulder-length hair; Gleidson, an electric guitarist who is also the younger brother of Gleucimar; and Wesdley, a computer-savvy bass guitarist. On the night of the show, the lineup included two additional members: a freelance percussionist and Marcelo, a backup singer and rhythm guitarist who is now a regular member of the band. Roberto wore all black, and Gleucimar wore a white skirt characteristic of northeastern Brazilian artisanal clothing and a white tank top, leather sandals, and a fabric headband across her forehead, calling attention to her long, straight black hair falling in front of her shoulders. The elements of their stage show, including their clothes, the band's name, their instrumentation, the song titles and lyrics, and the sound of the music, express the diverse musical and cultural influences of the band. They construct symbolic configurations that express meanings of difference and similarity between Fortaleza and Ceará and between these and Brazil, or rather, between the city, the state, and the nation. The symbolic content in their show is formed by various musical influences and visual imaginaries, all of which are subject to constant resignification. As Sahlins explains, "Meanings are reevaluated when they are realized in practice" (Sahlins 1990: 7).

After about a minute of instrumental vamping, Roberto approached the microphone. "Since the very beginning, we have proposed to contribute to Ceará's artistic scene," he announced over the sound of the heavy metal-influenced rhythm section. Next, the sound of the electric bass, electric guitar, and high hat commenced "Calango Eletrônico" (Electronic Lizard), followed by an acoustic guitar accompanying the fast-paced pé-de-serra rhythm of the forró triangle and ganzá, with the entrance of the zabumba playing a baião rhythm shortly thereafter. Next, the singers began a descending minor tetrachordal "whoa" sung in parallel thirds. The word calango, meaning lizard, is commonly used in the interior of Ceará (as opposed to the more common Portuguese word lagartixa), and functions here as both a visual and linguistic symbol of the sertão. The song's lyrics are about a lizard that uses the internet, and according to Roberto, reflect a tension between rurality and urbanity that he perceives as a characteristic of Fortaleza. He explained that lizards can be found on his front porch as much as they can in the sertão, and that in the song, they illustrate how despite this rapidly globalizing world, elements of local environment and culture persist.

The hour-and-twenty minute show featured guest appearances by local stars. The lead singer of Renegados, a local heavy metal band, carried 
his toddler on his shoulders onto the stage as he sang a duet with Roberto. To sing "Homens de Maracatu" (Men of Maracatu), Gleucimar invited Calé Alencar to the stage, calling him one of the "great men of maracatu." The duet, which Gleucimar composed after watching Fortaleza's maracatu processions from the grandstands during carnaval, is an homage to the men who lead these percussion-based ensembles. Before leaving the stage, Calé emphasized the importance of groups like Eletrocactus in the construction of "a new movement of art and culture." Gleucimar thanked him by repeating the song's lyrics, "He creates maracatu where life does not create it, he lives maracatu where life does not live it."

The Theatro José de Alencar is an important venue for Eletrocactus. In 2006 they played with other regionalist bands as part of an event called Sexta da Música, organized and produced by Calé Alencar, which was filmed and released on DVD. Their release party, which was part of a larger month-long celebration of the theater's centennial, was their first headlining show at the venue. The theater, their first choice, fits with the band's mission because it plays into the cultural imaginary of Fortaleza as a significant image in local memory and an evolving tool in the construction of fortalezensidade, Fortaleza-ness.

\section{“Maracatunaíma": The Song Without Character}

The "cadenced" maracatu cearenese rhythm - played on an iron triangle, caixa (snare) and bumbo (bass drum)—slowly fades in, beginning Eletrocactus' original recording of the song "Maracatunaíma" on their EP Ver Viajar. The snare plays quarter note triplets over the first two beats in $4 / 4$ time, the bass drum on beats three and four, and the triangle on all four beats, muted on beats one and three and fully sounding its shallow, dull timbre on beats two and four. After twenty seconds of nothing but maracatu cearense, the electric guitar and electric bass enter, playing a twelve-bar blues riff that sounds more rockabilly than rock and roll, like a twangy caricature of the blues. Gledson then enters on vocals another twenty-five seconds later, growling the melody with clipped enunciation and a warbling tone, before ending the first phrase with a "whoo" reminiscent of Warren Zevon's "Warewolves of London." Roberto joins in on the harmony of the chorus, and the maracatu percussion drops out, with the drums, bass, and guitar only emphasizing 
the downbeat of the measure and the following eight note, and later reiterating the quarter-note triplets of the maracatu. Following the refrain, a blues harmonica solo improvises around the melody with the drums now playing a rock beat, and then Gledson takes a solo on the electric guitar through the next verse and refrain. Roberto's vocals and the maracatu rhythm return for two last verses and refrains, and then the song ends abruptly on a tonic chord with an added flat seven, suggesting the mixolydian mode, common to blues and much northeastern Brazilian music.

The 12-bar blues of the bass and guitar is juxtaposed with the maracatu cearense of the percussion throughout the song's verses, the two sounds layered but distinct, and their rhythms only synchronizing during the song's chorus. During the blues harmonica and guitar solos, the maracatu rhythm vanishes altogether. Yet the sentiment remains clear: this song is a playful example of Eletrocactus' deliberate attempt to combine blues and rock with music from Ceará. Gleucimar explained how blues was a lingua franca among the musicians in the group. When they began penning "Maracatunaíma," they needed to research maracatu, not the blues. They had to learn the technique to play the iron triangle, for example. "People already know the blues," she said, "so you have to research what is from here, which is the irony." It was rock and roll-and not maracatu cearense — that "formed our generation," she said. At a music festival in 2007, they performed "Maracatunaíma," and as they recall, nobody understood what they were playing. People complained that they were playing blues improperly. The maracatu rhythm was not only unintelligible to the audience, but it was mistaken for a poorly played blues rhythm. Calé Alencar happened to be in attendance, and later told the band that he tried explaining to people around him that if they ignored the electric guitar, they could hear the maracatu beat, but the listeners remained doubtful.

The members of Eletrocactus understand their musical project not as a reflection or product of globalization and flows, but rather as an updating of what is already theirs, or rather, taking something which they identify as their own - rock music - and inserting themselves into it-maracatu cearense. Although rock music was an example of globalization through the 1980s, its ubiquity has since decontextualized and deterritorialized it, making the "rock aesthetic the core practice of popular music in the world" (Regev 2003: 222). Gleucimar emphasizes, "It's great to see yourself represented in a film, and that doesn't happen in Brazil.” Roberto continued, 
"When you see a photo of yourself in a friend's photo album, you feel happy. You feel a sense of pride when you see yourself. We want people to recognize themselves in our music." In their minds, they are not mixing cearense music with American music. They are creating rock music in which they and their listeners can feel a sense of regional pride. Yet their prior lack of familiarity with maracatu highlights the semiotic tension in their work: maracatu cearense is a symbol of Ceará, but it is not one they already knew. While the band hopes to disseminate feelings of belonging and recognition among any person from Ceará or Fortaleza who hears their music, they do so not only by emphasizing the sound of maracatu cearense, but also through their lyrics in their song "Maracatunaíma."

Mário de Andrade's novel Macunaíma, published in 1928, is considered an important work of Brazilian nationalist modernism. Its development is closely linked to "Mário de Andrade's profound musical experience; above all, to the meditation about the system of borrowing among classical and popular (traditional) music" (Souza 2003: 25). Interspersed with ambiguous characters and secondary plots, the central narrative concerns the journey of the protagonist Macunaíma, "moleque preto e retinto" (a child with jet-black skin), with both indian and black brothers, and who transforms into a white prince with blue eyes. Macunaíma travels Brazil in search of the "muiraquita," a magic amulet which is continually lost and found throughout the narrative.

According to Gilda de Mello e Souza, the book Macunaíma "represents an exremely complex meditation about Brazil, made through a savage discourse, rich in metaphors, symbols and allegories" (2003: 84). By juxtoposing indigenous, African and European elements, Mário de Andrade expresses the plural character of Brazilian cultural identity, delineated by difference. Macunaíma's search for the lost amulet metaphorically explains his impossible search for his own identity, reflecting the idea of the "hero without character," or rather, an unfinished Brazilian identity, marked by diverse influences.

In the lyrics of the song, "Maracatunaíma," Eletrocactus juxtoposes maracatu cearense with the character of Macunaíma, specifically in the indigenous, African, and European elements emplyed in both, evoking the praise of miscegenation widespread in Brazil in the 1930s and 1940s, when there was an intellectual and political movement to unify the country around common representations. In that period, they searched for elements that mark Brazilian uniqueness to distinguish Brazil from other countries. Feijoada and 
samba are prime examples of their elevation of cultural practices and nationalist symbols. Schwarcz explains, "this is the same miscegenation that is resignified in malandragem (trickery) at the beginning of the century and is converted into a national icon in the lazy figure of Macunaíma" (1995: 51). The project of Brazilian national identity could be compared to the artistic project of Eletrocactus in the use of elements from traditional culture that are transformed into signs of Brazilian identity.

From the band's point of view, the juxtaposition of maracatu with Macunaíma indexes the local, regional, and national. In the year Mário de Andrade published Macunaima, he also published his "Essay on Brazilian Music," in which he called on Brazilian composers of Western art music to find a national compositional voice by invoking elements of local Brazilian musics. This is, more or less, what Gleucimar has in mind with Eletrocactus: to transcend the local by indexing it, becoming regionally or nationally relevant by first expressing a local sound. Eletrocactus may not be outwardly nationalist like Andrade was, but by combining these two signs of miscegenation (one local and musical, and the other national and literary) in this song, they articulate various dimensions of belonging, both racial and geographical. Additionally, the band's intent is similar to Macunaíma's purpose: the search for belonging. Describing the song, Gleucimar points out that Macunaíma is a book about a "hero without character":

And we live in this confusion. Who are we? We're all this. We're nobody. This is the identification that we want to have [in the song]. Where do we come from? There's so much miscegenation. Our Brazilian birthright is this.

The song's lyrics include words like paxiúba, Iriqui, and muiraquitã, suggesting indigeneity, contain references to a "moleque preto retinto," a child with jet-black skin—Macunaíma himself—and list the names "Piaimã," "Pietro," and "Pedro," referencing both indigenous and European ancestry. The song's narrative describes the "moleque preto" dancing maracatu, itself an allusion to the idea of African ancestry in the formation of Brazil. Schwarcz explains that "symbols do not only reflect, but they also create meaning. They are products, but they are also a production: they construct values and feelings" (Schwarcz 2008: 44).

Brasilidade (Brazilian-ness) is most visible with the band in light of their intuition to insert themselves into global flows (Appadurai 2003). Gleucimar 
and Roberto both mentioned that they hope to perform abroad, specifically in Europe and the Middle East. As they begin to expand their scope, it seems that they begin to prioritize brasilidade over cearensidade, the national over the regional.

The first recording of "Maracatunaíma" emphasized maracatu presumably because they were thinking of themselves and their recording in a regional context. Making music in which people from Fortaleza can recognize themselves is relevant in the context of the city or the state. Cearensidade, representing the state as a whole, is relevant on a national scene. And representing the nation (as well as an internationalized youth culture) becomes relevant in an international milieu.

The recording of "Maracatunaíma" from their new $\mathrm{CD}-$ much like their performance at the $\mathrm{CD}$ release party-differs in several significant ways from the original EP recording described above. The song begins with a swing ride rhythm played on the hi-hat, and after only one second of solo percussion, the guitar and bass enter. The familiar guitar riff from the previous recording and a new, more complex walking bass line begin at ten seconds, when the ride rhythm gives way to a subtle maracatu cearense rhythm, played on the drum set rather than maracatu drums. The iron triangle is also quiet and buried in the mix, and is accompanied by a hi-hat and a steel triangle- the kind used in forró-that has a higher and tinnier timbre. The guitar and bass parts seem more complicated than before, more blues-like, less rockabilly, and the counterpoint between the two creates most of the song's interest. Gledson's voice is restrained, only growling the first syllable of the first word of each phrase, singing with a clearer, straighter tone in general. The "whoo" before the refrain is replaced with the band members shouting what sounds like, "Yeah, boy!" in English. Roberto's harmonies in the chorus are quieter. And there is no harmonica solo, leaving the song one verse shorter, now only three minutes, twenty-two seconds as opposed to the five minutes, eighteen seconds of the EP version. Like the earlier recording, this version also ends with a tonic seventh chord. Even though the triangles play the maracatu pattern through the refrain, this recording is generally more blues than maracatu.

As the band tries to enter into the mainstream, striving for radio play and exposure to audiences outside of the Northeast and even outside of Brazil, their music seems less self-consciously cearense. Roberto explains the change: 
Before we had a real aesthetic preoccupation. Now we make music the way we like, without references. We don't need to worry about mixing things. Before, they would say, "Let's do a baião with blues." Now it's just like, "Matuto Blues" (Northeastern hillbilly blues). Blues, played the way we play it.

\section{CONCLUSION}

Roberto emphasizes the notion that they want their fans (or potential fans) to identify with Eletrocactus' music. But he also confirms the problem that many of the images they hope listeners will identify with are new to their audiences and to themselves. He explains:

We want people to be able to identify with what we play. [...] (Our EP) "Ver Viajar" talks about the beauty of nature, like the passionfruit flower, which was on the cover of our EP. But even I didn't know what a passionfruit flower was.

Gleucimar interjected: “Because Ceará isn't only sertão. It's hills and sertão."

Roberto continued: "There are many here, but I had never seen a passionfruit flower."

This is about essentialized versus constructed conceptions of identity. For some, there are signs, concepts and sounds that are essentially cearense. For others there is no cearensidade, but rather many, and so there are also many signs, which can change and vary. Martin Stokes explains, "People can [...] use music to locate themselves in quite idiosyncratic and plural ways" (1997: 3). The members of Eletrocactus yearn for an essential cearensidade they can tap into. They want a direct way to musically say that they are from Ceará. But because no such cearensidade exists, they must cobble together various images and sounds put forward by musicians before them, and invent new ones in the process. This act, creating new signs, new aural metonyms of the city, state, and nation, occurred with each musical style that was seen as an important sign of Ceará by Eletrocactus. Luiz Gonzaga linked baião to the Northeast. The Pessoal do Ceará and Calé Alencar linked maracatu cearense to Ceará. Dona Zefinha linked reisado to the interior. These rhythms and cultural practices became signs over time, due to repeated intentional of use of them as signs. For the social imaginary to be entrenched in the minds of people, there must be a "continuity of meaning:" "symbols, allegories, and myths 
only create roots when there is social and cultural terrain upon which they can feed" (Carvalho 1990: 89).

Eletrocactus began by self-consciously combining pre-existing signs of the region and of their identities as young musicians from the periphery of Fortaleza. Now they make "matuto blues," not half northeastern hillbilly/half blues, but a synthesis of the two. On their myspace page, Eletrocactus writes:

Does a truly cearense music exist? This is the latent question in each chord intoned by the musicians of the band Eletrocactus, whose music provides a soundtrack to routes in search of a cearense music that dialogues amiably with the many disparate tendencies of regional, Brazilian, and international music.

Rather than answering this question, their music seems to continually ask it. Eletrocactus simultaneously represents and creates cearensidade, nordestinidade and brasilidade in their music. As their audience expands, so does the way they wished to portray themselves. To audiences in Ceará, they emphasize Fortaleza and fortalezensidade. To the Northeast, they emphasize cearensidade. To a Brazilian audience, they emphasize nordestinidade. Internationally, they emphasize brasilidade. For their listeners and fans to experience feelings of pride or self-recognition, the band members feel they must convincingly convey musical representations of these places. Yet in order to comprehend the musical signs of Fortaleza, Ceará or Brazil, listeners must be able to recognize them as such. The process by which musical "mediational signs" or "sign-interpretants" are created and then become recognizable and meaningful allows them to ultimately evoke feelings of pride and recognition as "emotional interpretants." Turino understands music as capable of inspiring feelings like love and hate, allowing listeners to "realize personal and social identities." But music also helps people construct individual and group identities by inspiring feelings of selfrecognition that can only occur when the music successfully functions as a mediational sign. For Eletrocactus, the city, state, and nation are places to be imagined musically, and by reiterating pre-existing musical signs and creating new ones, they actively construct new musical identities.

\section{BIBILIOGRAPHY}

ALBUQUERQUE JÚNIOR, Durval Muniz de. 1999. A Invenção do Nordestee 
Outras Artes. Recife: Fundação Joaquim Nabuco/Editora Massangana. ANDRADE, Mário de. 1981. Danças Dramáticas do Brasil. Belo Horizonte: Itatiaia/ INL/ Pró-memória.

APPADURAI, Arjun. 2003. The Social Life of Things. Cambridge: The Press Syndicate of the University of Cambridge.

ARAGÃO, Raimundo Freitas. 2005. Das práticas marítimas modernas à elaboração da imagem turística de Fortaleza/Ceará. Master's thesis, Centro de Ciências, Universidade Federal do Ceará - Fortaleza

BARbAlho, Alexandre. 2005. A Modernização da Cultura: Políticas para o Audiovisual nos Governos Tasso Jereisssati e Ciro Gomes (Ceará/1987-1998). Fortaleza: Imprensa Universitária.

BARROSO, Oswald. 2002. Theatro José de Alencar: O Teatro e a Cidade. Fortaleza: Terra da Luz Editorial.

BASTIDE, Roger. 1945. Imagens do Nordeste Místico em Branco e Preto. Rio de Janeiro: O Cruzeiro.

BOAS, Franz. 1940. Race, Language, and Culture. Chicago: University of Chicago Press.

BRANDÃO, Adelino. 1971. "Influências Árabes na Cultura Popular e Folclore do Brasil”. Revista Brasileira de Folclore 11:29: 65-84.

CARVALHo, Gilmar de. 1983. "Referências Cearenses na Música de Ednardo". Revista de Comunicação Social da UFC.. Fortaleza: UFC. Edição condensada. http://www.ednardo.art.br/materio7.htm.

CARVALHO, José Murilo de. 1990. A Formação das Almas: o Imaginário da República no Brasil. São Paulo: Companhia das Letras.

CASTRO, Wagner. 2008. No Tom da Canção Cearense: do Rádio e Tv, dos Lares e Bares na Era dos Festivais (1963-1979). Fortaleza: Edições UFC.

costA, Francisco Augusto Pereira da. 1908. Folk-lore Pernambucano. Recife: Arquivo Publico Estadual.

CRUZ, Danielle Maia. 2011. Maracatus no Ceará: Sentidos e Significados. Fortaleza: Edições UFC.

DAMATTA, Roberto da. 1987. "Relativizando: uma introdução à antropologia social”. In: Digressão: A fábula das três raças, ou o problema do Racismo à Brasileira. Rio de Janeiro: Rocco.

FERREIRA, Ascenso. 1951. É de Tororó. Rio de Janeiro: Livraria Editora da Casa do Estudante do Brasil. 
FRY, Peter. 2005. A Persistência da Raça. Rio de Janeiro: Civilização Brasileira. GUERRA-PEIXE, César. 1980. Maracatus do Recife. (Coleção Recife - v. XIV). Prefeitura da cidade do Recife; Secretaria de Educação e Cultura; Fundação de Cultura Cidade do Recife. Editora Irmãos Vitale.

LIMA, Ivaldo Marciano de França. 2008. Maracatus e Maracatuzeiros:

Desconstruindo Certezas, Batendo Afayas e Fazendo Histórias. Recife: Bagaço. LIMA, Ivaldo Marciano de França. 2009a. Identidade Negra no Recife: Maracatus e Afoxés. Recife: Bagaço.

LIMA, Ivaldo Marciano de França ; GUILLEN, Isabel Cristina Martins. 2007. Cultura Afro-Descendente no Recife: Maracatus, Valentes, e Catimbós. Recife: Bagaço.

LIMA, Maria Rosalete Fontes. 2009. Festa e Conflito: Visões do Brasil em Oswald de Andrade. Master's Thesis in Social Sciences, Universidade Federal do Ceará, Ceará.

MAGALDI, Cristina. 1999. "Adopting Imports: New Images and Alliances in Brazilian Popular Music of the 1990s”. Popular Music, 18(3):309-329.

MENDES, Maria das Dores Nogueira. 2007. "Palmilhando um Chão Sagrado: a Construção da Topografia nas Canções do Pessoal do Ceará”. In: N. Costa (org.), O Charme dessa Nação: Música Popular, Discurso e Sociedade Brasileira. Fortaleza: Expressão Gráfica e Editora. pp. 401-420.

PAZ, Ermelinda A. 2002. O Modalismo na Música Brasileira. Brasília: Editora MUSIMED.

Pimentel, Mary. 1995. Terral dos Sonhos: o Cearense na Música Popular Brasileira. Fortaleza: Banco do Nordeste do Brasil/Gráfica e Editora Arte Brasil.

REAL, Katarina. 1967. O Folclore no Carnaval do Recife. Rio de Janeiro: Ministério da Educação e Cultura. Campanha de defesa do folclore brasileiro.

REGEV, Motti. 2003. “"Rockization': Diversity within Similarity in World Popular Music”. In: Ulrich Beck (org.), Global America?: The Cultural Consequences of Globalization. Liverpool: Liverpool University Press. pp. 222-245

REILY, Suzel Ana. 1997. “Macunaíma’s Music: National Identity and Ethnomusicological Research in Brazil”. In: M. Stokes (org.), Ethnicity, Identity and Music: The Musical Construction of Place. New York: Berg Publishers. pp. 71-96. 
RODRIGUES, Nina. 1932. Os Africanos no Brasil. São Paulo: Companhia Editora Nacional.

SAHLINS, Marshall. 1990. Ilhas de História. Rio de Janeiro: Zahar Editores. SCHWARCZ, Lilia Katri Moritz. 1995. Complexo de Zé Carioca- Notas sobre uma identidade mestiça e malandra. Revista Brasileira de Ciências Sociais, São Paulo, Anpocs, p. 49-63.

SCHWARCZ, Lilia Katri Moritz. 2008. "Assim é, se lhe parece.” Revista de História da Biblioteca Nacional, 3(34):44-49.

SILVA, Ana Cláudia Rodrigues. 2004. Vamos Maracatucá: um Estudo sobre os Maracatus Cearenses. Master's Thesis, Programa de Pós-Graduação em Antropologia, Universidade Federal de Pernambuco - Recife.

SOUZA, Marina de Mello e. 2002. Reis Negros no Brasil Escravista: História da Festa de Coroação de Rei Congo. Belo Horizonte: Editora UFMG. souzA, Gilda de Mello. 2003. O Tupi e o Alaúde: uma Interpretação de Macunaíma. São Paulo: Duas Cidades/Ed. 34. STOKES, Martin. 1997. "Introduction: Ethnicity, Identity and Music”. In: M. Stokes (org.), Ethnicity, Identity and Music: the Musical Construction of Place. New York: Berg Publishers. pp. 1-28.

TURINO, Thomas. 1999. "Signs of Imagination, Identity, and Experience: A

Peircian Semiotic Theory for Music”. Ethnomusicology, 43(2):221-255. TURINO, Thomas. 2008. Music as Social Life: the Politics of Participation.

Chicago: The University of Chicago Press.

VARGAS, Herom. 2007. Hibridismos Musicais de Chico Science \& Nação Zumbi.

Cotia, SP: Ateliê Editorial.

\section{Danielle Maia Cruz}

Doctoral student in sociology at the Universidade Federal do Ceará

CRUz, Danielle Maia and Rodrigues, L. C. Forthcoming. “Tempo de Carnaval: Políticas Culturais e Formulações Identitárias em Fortaleza”. Revista PROA

- Revista de Antropologia e Arte. (Accepted for publication in 2010.)

Rua Henriqueta Galeno. 96o. ap. 1301

Dionísio Torrres. 60-135-420

Fortaleza-Ceará, Brazil

dmaiacruz@yahoo.com.br 


\section{Michael B. Silvers}

Doctoral student in ethnomusicology at the University of California, Los Angeles

Silvers, Michael B. 2009. "Audio Review: Colombie: Nafer Durán, Roi du Vallenato / Colombia: Nafer Durán, King of Vallenato”. Yearbook for Traditional Music 41: 246.

2436 Langdale Ave.

Los Angeles, CA 90041 USA

michaelbsilvers@gmail.com

Received 30 September, 2011, approved 13 January, 2011 